\title{
INTEGRATED NUTRIENT MANAGEMENT ON SOYBEAN IN A COASTAL CHARLAND OF BANGLADESH
}

\author{
I. S. M. Farhad1 ${ }^{*}$, M. A. Rahman², E. Jahan ${ }^{3}$, M. G. Azam ${ }^{4}$ and N.R.Khan 5 \\ 1 Soil Science Division, BARI, Gazipur, Bangladesh \\ 2Department of Agronomy, SAU, Dhaka, Bangladesh \\ ${ }^{3}$ Department of Agricultural Chemistry, SAU, Dhaka, Bangladesh \\ ${ }^{4}$ RARS, BARI, Hathazari, Chittagong, Bangladesh \\ ${ }^{5}$ Department of Agriculture Extension, Manikganj, Bangladesh \\ *Corresponding author, E-mail: farhadsau@gmail.com
}

Key words: Cost and Return, Soybean nodulation, Yield

\begin{abstract}
A field experiment was conducted at Char Jangalia under MLT site, Laxmipur, a coastal district of southern Bangladesh, during Rabi season of 2015-16 to evaluate the effect of integrated nutrient management on growth and yield performance of soybean (var. Glycine max L.). Six treatment combinations, viz. $\mathrm{T}_{1}=$ Control, $\mathrm{T}_{2}=$ Farmers practice (25-15 Kg NP ha-1, $\mathrm{T}_{3}=100 \%$ recommended dose (30-25-55 Kg NP ha-1, K), $\mathrm{T}_{4}=50 \%$ recommended dose $+1.5 \mathrm{t} \mathrm{ha}^{-1}$ vermi compost, $\mathrm{T}_{5}=50 \%$ recommended dose $+5 \mathrm{t} \mathrm{ha}^{-1}$ compost and $\mathrm{T}_{6}=50 \%$ recommended dose $+1.2 \mathrm{~kg} \mathrm{ha}^{-1}$ bio fertilizer were tested. The experiment was laid out in randomized complete block design with 3 replications. There were significant differences among the different treatment combinations in terms of yield and yield contributing characters. Integrated nutrient management with application of 50\% of the recommended doses of urea, TSP, MoP, and biofertilizer (Bradyrhizobium) at the rate of $1.2 \mathrm{~kg} \mathrm{ha}^{-1}$ significantly increased most of the parameters, such as the plant height, number of nodule per plant, pods per plant, seeds per pod and seed yield. The highest seed yield $\left(2.93 \mathrm{t} \mathrm{ha}^{-1}\right)$ was recorded from $\mathrm{T}_{6}$ while the lowest seed yield $\left(1.83 \mathrm{t} \mathrm{ha}^{-1}\right)$ was obtained from $\mathrm{T}_{1}$. The highest gross return (Tk.117200 ha-1) and gross margin (Tk. $\left.71840 \mathrm{ha}^{-1}\right)$ was obtained from $\mathrm{T}_{6}$, whereas the lowest gross return (Tk. $70400 \mathrm{ha}^{-1}$ ) and gross margin (Tk.27880 ha $^{-1}$ ) was obtained from $\mathrm{T}_{1}$. The overall results indicated that the application of integrated nutrient management of a combination of bio fertilizer with $50 \%$ N-P-K (15$12.5-27.5 \mathrm{Kg} \mathrm{ha}^{-1}$ ) of the recommended dose produced the maximum nodulation and seed yield of soybean in the southern coastal char land.
\end{abstract}

\section{Introduction}

Soybean (Glycine max L.) is a good source of oil, protein, unsaturated fatty acids, minerals like $\mathrm{Ca}$ and $\mathrm{P}$ including vitamins A, B and D (Rahman, 1982). According to Kaul and Das (1986) it contains 40-45\% protein, 18-20\% edible oil, 24-26\% carbohydrate and a good amount of vitamins Moreover, soybean being a leguminous crop has the ability to fix atmospheric nitrogen (N) through root nodule bacteria (Bradyrhizobium japonicum) and thus it enriches the soil fertility.

Soybean is popular and economic mono oil seed crop in Laxmipur, a coastal district of southern Bangladesh. In Laxmipur district, the total soybean cultivation area is about 45 thousands hectares (Chowdhury et al., 2013). Until recently the cultivation of soybean was 
Farhad et al.

concentrated only in greater Noakhali area, though the cultivation has been expanded dramatically from only 5000 ha in 2005 (Satter et al., 2005) to 61000 ha in the districts of Bhola, Patuakhali, Faridpur, and even in the northern Bangladesh (Chowdhury et al., 2013). The expansion of cultivation about the high nutrient status of soybean as a human food is increasing in Bangladesh (Mannan et al., 2012).

The average yield of soybean in the world is about $3.0 \mathrm{t} \mathrm{ha}^{-1}$, while in Bangladesh it is only 1.2 $t$ ha $^{-1}$ (SAIC, 2007). Farmers of this coastal area generally grow local variety of soybean without or injudicious application of fertilizer. For this reason, the yield of soybean in this region is much below than that of potential yield level. Experimental evidences revealed that the crop was highly responsive to different fertilizers and the yield could be increased remarkably through judicious fertilization (BARI, 1988; Mohamed, 1984; Roy and Singh, 1986; Kazi et al., 2002).

Integrated nutrient management practices applied for soybean contributes to sustainable growth of yield and quality, influences soil health and reduces environmental risks. Use of organic manures with optimum rate of fertilizers under intensive farming system increased the turnover of nutrients in the soil plant system. The organic manures along with bio fertilizers help in reducing the dose of inorganic fertilizer, which in turn reduces the cost of cultivation and help in improving the soil health.

Therefore, this study was undertaken to analyze the effect of integrated nutrient management on nodulation, growth and yield of soybean in the southern coastal char land of Bangladesh.

\section{Materials and Methods}

A field experiment was conducted during Rabi season of 2015-2016 at Char Jangalia Multilocation Trial (MLT) site, Laxmipur district of southern coastal Bangladesh, which is under Young Meghna Estuarine Floodplain called Agro ecological Zone 18 to evaluate the effect of integrated nutrient management on soybean. Before conducting the experiment, initial composite soil samples at $0-15 \mathrm{~cm}$ soil depth over 10 spots were collected from the experimental plots and were analyzed in the laboratory following standard methods. The initial soil analysis values are presented in Table 1 . The experiment was laid out in randomized complete block design with 3 replications. The unit plot size was $4 \mathrm{~m} 3 \mathrm{~m}$. Soybean var. BARI Soybean- 5 variety was used as the test crop in this experiment. Treatments were : $T_{1}=$ Control, $\mathrm{T}_{2}=$ Farmers practice $\left(25-15 \mathrm{Kg} \mathrm{ha}^{-1}\right.$ of $\mathrm{N}-\mathrm{P}$, survey of 20 farmers), $\mathrm{T}_{3}=100 \%$ recommended dose (30-25-55 $\mathrm{Kg}^{-1}$ of N-P-K, FRG, 2012), $\mathrm{T}_{4}=50 \%$ recommended dose $+1.5 \mathrm{tha}^{-1}$ vermicompost, $\mathrm{T}_{5}=50 \%$ recommended dose $+5 \mathrm{tha}^{-1}$ compost and $\mathrm{T}_{6}=50 \%$ recommended dose $+1.2 \mathrm{~kg} \mathrm{ha}^{-1}$ biofertilizer. Seeds were taken in small polythene bags equal in weight for each pot and mixed with molasses @ 20g molasses $\mathrm{kg}^{-1}$ seeds. For each inoculation separate plastic bag was used and care was taken to avoid contamination of the inoculated and non-inoculated seeds. Then the inoculum (BinaSB-4) was mixed with the seeds @ $20 \mathrm{~g} \mathrm{~kg}^{-1}$ seeds for the treatment $\mathrm{T}_{6}$. The seeds were sown @ $60 \mathrm{~kg} \mathrm{ha}^{-1}$ on18 January 2016 in line with the spacing of $30 \mathrm{~cm} \times 10 \mathrm{~cm}$. Two irrigations were done during the crop duration. First irrigation was applied after 20 to 25 days of sowing before flowering and second irrigation at pod formation stage. Different intercultural operations and plant protection measures were taken as and when necessary to raise healthy crops. The crop was harvested on 20 April, 2016. Three (03) plants were randomly selected from each plot and carefully 
Integrated Nutrient Management on Soybean in a Coastal Charland of Bangladesh

uprooted to study the nodule number. Soil from the root was removed carefully and the nodules were separated and counted at 30 DAS, 60 DAS and at harvest. Data were collected on an individual plant basis from ten (10) randomly selected plants of each plot in such a way that the border effect was avoided for high precision. Plant height and number of branches plant $^{-1}$ were recorded during harvest. Number of pods plant ${ }^{-1}$, number of seeds pod ${ }^{-1}$ and $100-$ seed weight were recorded after harvesting of the crop. Plot yield was recorded and then converted to $t \mathrm{ha}^{-1}$. Analysis of variance and comparison of means were calculated separately with statistical package MSTAT-C programme (Gomez and Gomez, 1984). The means were compared using the least significance difference (LSD) test. The functional form of the linear relationship between a dependent variable $\mathrm{Y}$ and an independent variable $\mathrm{X}$ was calculated according to equation given by Gomez and Gomez, (1984). X represents the amount of change in $\mathrm{Y}$ for each unit change in $\mathrm{X}$.

Table 1. Chemical properties of initial soil (0 -15 cm depth) of the experimental field at Char Jangalia, MLT site, Laxmipur during Rabi season of 2015-16

\begin{tabular}{|c|c|c|c|c|c|c|c|c|c|c|c|c|}
\hline \multirow[t]{2}{*}{ Sample } & $\mathrm{pH}$ & EC & $\mathrm{OC}$ & OM & $\begin{array}{c}\text { Total } \\
\mathrm{N}\end{array}$ & $\mathrm{K}$ & $\mathrm{Ca}$ & $\mathrm{Mg}$ & $P$ & $\mathrm{~S}$ & Zn & B \\
\hline & & $\mathrm{dS} \mathrm{m}^{-1}$ & $(\%)$ & (\%) & $(\%)$ & \multicolumn{3}{|c|}{ Meq/100 g soil } & \multicolumn{4}{|c|}{$\mathrm{g} \mathrm{g}^{-1}$ soil } \\
\hline Avera & 6.7 & 1.58 & 0.9 & 1.54 & 0.08 & 0.11 & 5.0 & 2.3 & 9 & 46 & 1.95 & 0.66 \\
\hline Critical & - & - & - & - & 0.12 & 0.12 & 2.0 & 0.5 & 10 & 10 & 0.6 & 0.2 \\
\hline Interpretation & Neutral & $\begin{array}{l}\text { Non } \\
\text { saline }\end{array}$ & Low & Low & $\begin{array}{l}\text { Very } \\
\text { Low }\end{array}$ & Low & Optimum & $\begin{array}{l}\text { Very } \\
\text { High }\end{array}$ & Low & $\begin{array}{l}\text { Very } \\
\text { High }\end{array}$ & High & High \\
\hline
\end{tabular}

$\mathrm{EC}=$ Electrical Conductivity, $\mathrm{OC}=$ Organic Carbon, $\mathrm{OM}=$ Organic Matter

\section{Results and Discussions}

The soil of the experimental site was neutral in reaction having $\mathrm{pH} 6.7$ and non-saline (Table 1). The organic matter was low (1.5\%) and total $\mathrm{N}$ content was very low (0.08\%). Available $\mathrm{K}$ and $\mathrm{P}$ were below the critical level but available $\mathrm{S}, \mathrm{Ca}, \mathrm{Mg}, \mathrm{Zn}$ and $\mathrm{B}$ were exist in satisfactory level.

\section{Number of nodules plant ${ }^{-1}$}

The inoculation of Bradyrhizobium and chemical fertilization had a significant effect on total number of nodules plant ${ }^{-1}$ at different days after sowing (Table 2). Results indicated that the highest number of nodules plant ${ }^{-1}$ was observed in the treatment $T_{6}$ (76.3) at 60 days after sowing which was significantly different from other treatments. The lowest number of nodule plant $^{-1}$ (21.3) was recorded from control treatment $\left(T_{1}\right)$. The results further revealed that integrated use of Bradyrhizobium and 50\% chemical fertilizers (N-P-K) substantially increased the nodules number compared to other treatments. . The nodule number of plant was gradually decreased after 60 DAS till harvesting in all the treatments. The lowest number of nodule was recorded at harvesting stage in all the treatments, presumably due to root senescence during ripening stage of the crop. The reason of the maximum nodulation in inoculated plants was probably due to the fact that Bradyrhizobium aids in nodulation. These results comply with that of Egamberdiyeva et al. (2004) who observed significantly higher number of nodules produced in inoculated plants compared with uninoculated one. 
Farhad et al.

Table 2. Effect of integrated nutrient management on nodules per plant at different days after sowing (DAS) of Soybean var. BARI Soybean-5 at Char Jangalia, Laxmipur during 2015-16

\begin{tabular}{|c|c|c|c|}
\hline \multirow[t]{3}{*}{ Treatments } & \multicolumn{3}{|c|}{ Number of nodules per plant } \\
\hline & 30 & 60 & At harvesting \\
\hline & DAS & DAS & stage \\
\hline$T_{1}=$ Control & 6.5 & 21.3 & 1.4 \\
\hline $\mathrm{T}_{2}=$ Farmers practice $\left(25-15 \mathrm{Kg}_{\mathrm{ga}}{ }^{-1}\right.$ of $\left.\mathrm{N}-\mathrm{P}\right)$ & 8.1 & 32.5 & 2.5 \\
\hline $\mathrm{T}_{3}=100 \%$ recommended dose & 11.2 & 41.1 & 2.7 \\
\hline $\begin{array}{l}\mathrm{T}_{4}=50 \% \text { recommended dose }+1.5 \mathrm{tha}^{-1} \\
\text { Vermicompost }\end{array}$ & 14.5 & 59.8 & 4.1 \\
\hline $\mathrm{T}_{5}=50 \%$ recommended dose $+5 \mathrm{tha}^{-1}$ Compost & 14.2 & 54.2 & 3.5 \\
\hline $\begin{array}{l}\mathrm{T}_{6}=50 \% \text { recommended dose }+1.2 \mathrm{~kg} \mathrm{ha}^{-1} \\
\text { Biofertilizer }\end{array}$ & 23.7 & 76.3 & 5.2 \\
\hline LSD (0.05) & 2.28 & 6.96 & 1.20 \\
\hline CV (\%) & 9.8 & 8.2 & 11.2 \\
\hline
\end{tabular}

Recommended dose: 30-25-55 Kg ha-1 of N-P-K according to FRG, 2012

\section{Growth, yield and yield contributing characters}

Plant height of soybean responded significantly to the integrated use of Bio fertilizer (Bradyrhizobium) and chemical fertilizers, N-P-K (Table 3). The maximum plant height was observed in the treatment $T_{6}(67.2 \mathrm{~cm})$ followed by the treatment $T_{4}(64.4 \mathrm{~cm})$ and the lowest in the control treatment $(48.3 \mathrm{~cm})$. The result was similar to the findings of Singh and Rai (2005) who observed that the integrated use of chemical fertilizers and bio-fertilizer increased plant height significantly in soybean.

The maximum number of branches plant ${ }^{-1}$ (3.3) was observed in $T_{6}$ treatment which was statistically identical with $T_{4}$ and $T_{5}$ treatment, whereas the lowest number of branches plant ${ }^{-1}$ (2.2) in $\mathrm{T}_{1}$ (control) treatment.

Pods plant ${ }^{-1}$ and seeds pod $^{-1}$ was significantly influenced by the integrated use of Bradyrhizobium with 50\% of the recommended dose of chemical fertilizers (Table 3). Maximum number of pods plant ${ }^{-1}(48.4)$ and seeds pod $^{-1}(2.25)$ was recorded in the treatment $T_{6}$ followed by the treatment $\mathrm{T}_{4}$. The minimum pods plant- 1 (34.3) and seeds pod-1 (1.93) was in T1. The result related to pods plant ${ }^{-1}$ was similar to the finding of Tomar et al.(2004), who observed that soybean plants treated with Bradyrhizobium inoculants significantly increased the number of pods plant ${ }^{-1}$.

On the other hand, seeds pod ${ }^{-1}$ was similar to the study of Jain and Trivedi (2005) who reported that the soybean plants treated with Bradyrhizobium alone or in combination with different levels of chemical fertilizers gave highest number of seeds pod ${ }^{-1}$. The maximum pod length $(3.33 \mathrm{~cm})$ was observed in $\mathrm{T}_{6}$ treatment which was statistically significant with all other treatments. The maximum 100- seed weight $(12.4 \mathrm{~g})$ was recorded in $\mathrm{T}_{6}$ treatment which was statistically at par with $T_{3}, T_{4}$ and $T_{5}$ treatments, while the lowest 100 seed weight $(11.7 \mathrm{~g})$ was in $\mathrm{T}_{1}$ treatment.

Seed yield was significantly influenced by the integrated use of Bradyrhizobium with or without organic and inorganic fertilizers. The seed yield varied from 1.83 to $2.93 \mathrm{t} \mathrm{ha}^{-1}$ in the different 
Integrated Nutrient Management on Soybean in a Coastal Charland of Bangladesh

treatments. The maximum seed yield $\left(2.93 \mathrm{t} \mathrm{ha}^{-1}\right)$ was observed by the application of Bradyrhizobium with $50 \%$ of the recommended dose of chemical fertilizers (N-P-K) followed by the treatment $\mathrm{T}_{4}\left(2.78 \mathrm{t} \mathrm{ha}^{-1}\right)$. The lowest seed yield $\left(1.83 \mathrm{t} \mathrm{ha}^{-1}\right)$ was recorded in the uninoculated treatment (control plot).

Table 3. Effect of integrated nutrient management on yield and yield contributing characters of soybean var. BARI Soybean-5 at Char Jangalia, Laxmipur during 2015-16

\begin{tabular}{lccccccc}
\hline Treatments & $\begin{array}{c}\text { Plant } \\
\text { height } \\
(\mathrm{cm})\end{array}$ & $\begin{array}{c}\text { Branches } \\
\text { plant }^{-1} \\
(\mathrm{no})\end{array}$ & $\begin{array}{c}\text { Pods } \\
\text { plant } \\
\text { (no.) }\end{array}$ & $\begin{array}{c}\text { Pod } \\
\text { length } \\
(\mathrm{cm})\end{array}$ & $\begin{array}{c}\text { Seeds } \\
\text { pod }^{-1} \\
\left(\text { no. }^{-}\right)\end{array}$ & $\begin{array}{c}\text { 100- seeds } \\
\text { weight } \\
(\mathrm{g})\end{array}$ & $\begin{array}{c}\text { Seed yield } \\
\left.\text { ( ha }^{-1}\right)\end{array}$ \\
\hline $\mathrm{T}_{1}$ & $48.3 \mathrm{~d}$ & $2.2 \mathrm{~d}$ & $34.3 \mathrm{~d}$ & $3.06 \mathrm{c}$ & $1.93 \mathrm{c}$ & $11.7 \mathrm{~b}$ & $1.76 \mathrm{e}$ \\
$\mathrm{T}_{2}$ & $54.5 \mathrm{c}$ & $2.5 \mathrm{c}$ & $37.6 \mathrm{c}$ & $3.10 \mathrm{c}$ & $1.98 \mathrm{c}$ & $11.8 \mathrm{~b}$ & $2.15 \mathrm{~d}$ \\
$\mathrm{~T}_{3}$ & $59.1 \mathrm{~b}$ & $2.9 \mathrm{~b}$ & $44.5 \mathrm{~b}$ & $3.11 \mathrm{c}$ & $2.11 \mathrm{~b}$ & $12.2 \mathrm{a}$ & $2.57 \mathrm{c}$ \\
$\mathrm{T}_{4}$ & $64.4 \mathrm{a}$ & $3.1 \mathrm{a}$ & $47.1 \mathrm{ab}$ & $3.18 \mathrm{~b}$ & $2.18 \mathrm{ab}$ & $12.3 \mathrm{a}$ & $2.78 \mathrm{~b}$ \\
$\mathrm{~T}_{5}$ & $63.7 \mathrm{a}$ & $3.1 \mathrm{a}$ & $45.7 \mathrm{~b}$ & $3.18 \mathrm{~b}$ & $2.16 \mathrm{ab}$ & $12.2 \mathrm{a}$ & $2.71 \mathrm{bc}$ \\
$\mathrm{T}_{6}$ & $67.2 \mathrm{a}$ & $3.3 \mathrm{a}$ & $48.4 \mathrm{a}$ & $3.33 \mathrm{a}$ & $2.25 \mathrm{a}$ & $12.4 \mathrm{a}$ & $2.93 \mathrm{a}$ \\
\hline $\mathrm{LSD}(0.05)$ & 3.54 & 0.21 & 2.53 & 0.05 & 0.109 & 0.37 & 0.14 \\
$\mathrm{CV}(\%)$ & 4.48 & 5.27 & 6.43 & 2.40 & 5.87 & 1.79 & 7.25 \\
\hline
\end{tabular}

$\mathrm{T}_{1}=$ Control, $\mathrm{T}_{2}=$ Farmers practice, $\mathrm{T}_{3}=100 \%$ rec. dose (FRG, 2012), $\mathrm{T}_{4}=50 \%$ rec. dose $+1.5 \mathrm{t}$ ha ${ }^{-1}$ Vermicompost, $\mathrm{T}_{5}=50 \%$ rec. dose $+5 \mathrm{t} \mathrm{ha}^{-1}$ Compost, $\mathrm{T}_{6}=50 \%$ rec. dose $+1.2 \mathrm{~kg} \mathrm{ha}^{-}$ 1Biofertilizer

From the simple regression (Table 4) it was found that the regression co-efficients for plant height, branches plant ${ }^{-1}$, pods plant ${ }^{-1}$, pod length, seeds pod $^{-1}$ and 100 - seeds weight were positively significant with yield indicating that increase in the values of these characters would increase the yield of the crop. In case of plant height, if 1.0 unit of plant height were increased then yield would be increased by 0.06 unit. Similarly, in case of branches plant ${ }^{-1}$, pods plant ${ }^{-1}$, pod length, seeds pod ${ }^{-1}$ and 100 seeds weight yield would be increased by 1.05 units, 0.078 unit, 2.80 units, 3.54 units and 1.54 units, respectively.

Table 4. Simple regression between yield and yield contributing characters

\begin{tabular}{lcc}
\hline Plant characters & Intercept (a) & Slope (b) \\
\hline Plant height & -1.2038 & $0.0619^{* * *}$ \\
Branches plant $^{-1}$ & -0.523 & $1.0549^{* * *}$ \\
Pods plant $^{-1}$ & -0.854 & $0.0777^{* * *}$ \\
Pod length $_{\text {Seeds pod }}^{-1}$ & -9.5495 & $2.8079^{*}$ \\
100 seeds weight $^{*}$ & -4.9438 & $3.5339^{* * *}$ \\
\hline
\end{tabular}

*= Significant at $5 \%$ level $\quad * *=$ Significant at $1 \%$ level

\section{Cost and Return Analysis}

From the cost and return analysis, the maximum gross return and gross margin Tk.117200 $\mathrm{ha}^{-1}$ and Tk.71840ha ${ }^{-1}$ respectively were recorded from the treatment $\mathrm{T}_{6}$ which was $50 \%$ recommended dose $(\mathrm{N}-\mathrm{P}-\mathrm{K})+1.2 \mathrm{~kg}$ ha-1 biofertilizer. The lowest gross return and gross margin of Tk.70400 ha ${ }^{-1}$ and Tk.27880 ha-1, respectively were obtained from the control treatment (Table 5). 
Farhad et al.

Table 5. Cost and return analysis of BARI soybean-5 as influenced by integrated nutrient management at Char Jangalia, Laxmipur during 2015-16

\begin{tabular}{cccc}
\hline Treatments & $\begin{array}{c}\text { Gross Return } \\
(\text { Tk. ha }\end{array}$ & $\begin{array}{c}\text { Total Variable Cost } \\
\left(\text { Tk. ha }^{-1}\right)\end{array}$ & $\begin{array}{c}\text { Gross Margin } \\
\left(\text { Tk. ha }^{-1}\right)\end{array}$ \\
\hline $\mathrm{T}_{1}$ & 70400 & 42520 & 27880 \\
$\mathrm{~T}_{2}$ & 86000 & 45926 & 40074 \\
$\mathrm{~T}_{3}$ & 102800 & 47960 & 54840 \\
$\mathrm{~T}_{4}$ & 111200 & 65740 & 45460 \\
$\mathrm{~T}_{5}$ & 108400 & 63240 & 45160 \\
$\mathrm{~T}_{6}$ & 117200 & 45360 & 71840 \\
\hline
\end{tabular}

Input and output price per Kg: Soybean seed $=$ Tk. 60, Urea $=$ Tk. $16, \mathrm{TSP}=\mathrm{Tk} .22, \mathrm{MoP}=\mathrm{Tk} .15$, Vermicompost $=$ Tk. 15, Compost $=$ Tk. 4, Bio-fertilizer $=$ Tk.100 and Soybean $=$ Tk. 40 .

\section{Conclusion}

Based on the results, it may be concluded that integrated nutrient management of bio-fertilizer (Bradyrhizobium) along with 50\% of the recommended dose of chemical fertilizers (N-P-K) was more effective than other fertilizer management packages in producing seed yield and economic return of soybean cultivation in the char areas under Young Meghna Estuarine Floodplain soil (AEZ 18f) of Bangladesh.

\section{References}

Bangladesh Agricultural Research Council (BARC). 2012. Fertilizer Recommendation Guide. New Airport Road, Farmgate, Dhaka.Pp.85-96.

Bangladesh Agriculture Research Institute (BARI). 2006. Krishi Projukti Hatboi (in Bangla). $4^{\text {th }}$ ed., Bangladesh Agricultural ResearchInstitute, Gazipur, Bangladesh. Pp. 209-211.

Chowdhury, M. M. U., M. J. U. Sarker., A.K. Choudhury.,I.S.M. Farhad., S.K. Bhowal, and K. M. F. Hossain. 2013. Soybean cultivation in coastal area of Noakhali. On-Farm Research Division, Bangladesh Agricultural Research Institute, Gazipur, Bangladesh. p.1.

Egamberdiyeva, D., D. Qarshieva and K. Davranov. 2004. The Use of Bradyrhizobiumto enhance growth and yield of soybean in calcareous soil in Uzbekistan. J. Plant Growth Regul.23: 5457.

Gomez, A. K. and A. A. Gomez. 1984. Statistical Procedure for Agricultural Research. International Rice Research Institute. John Willy and Sons., Singapore.p. 680.

Hoque, M.S. and M.A. Hashem. 1994. Field evalution of some promising Bradyrhizobium inoculants on soybean and groundnut at different locations. Bangladesh Agricultural University, Research Program, 8: 118-122.

Jain, P.C. and S.K. Trivedi. 2005. Response of soybean (Glycine max L. Merrill) to phosphorus and biofertilizers. Legume Res. 28 : 30-33.

Kaul, A. K. and M. L. Das. 1986. Oilseeds in Bangladesh. Bangladesh Canada Agriculture Sector Team, Ministry of Agriculture, Government of the People's Republic of Bangladesh, Dhaka, p. 324. 
Integrated Nutrient Management on Soybean in a Coastal Charland of Bangladesh

Kazi, B. R., F.C. Oad and A. Lakho. 2002. Effect of irrigation frequencies on growth and yield of soybean. Pakistan J. Appl Sci., 2: 661-662.

Mannan, M. A., M. A. Karim, M. M. Haque, Q. A. Khaliq, H. Higuchi and E. Nawata. 2012. Response of soybean to salinity: I. Genotypic varistions in salt tolernce at the vegetative stage. Trop. Agr. Develop. 56: 117-122.

Mohamed, S.A. 1984. Effect of irrigation water and fertilization on yield and water use efficiency of corn plants in fayoum governorate, Moshtohor, Egypt. Ann. Agril. Sci 20:221-235.

Rahman, L. 1982. Cultivation of Soybean and Its Uses. City Press, Dhaka. Pp. 5-7.

Roy, R. K. and K. S. P. Singh.2005. Response of popcorn (Zea mays) to plant population and nitrogen. Indian J. of Agron.31: 87-92.

SAIC. 2007. SAARC Agricultural Statistics of 2006-07. SAARC Agricultural Information Centre, Farmgate, Dhaka-1215. p. 23.

Satter, M.A., M. Rahman and M.S. Alam. 2005. Krishi Projucti Hatboi. Bangladesh Agricultural Research Institute, Gazipur1701, Bangladesh, p. 155.

Singh, R. and R.K. Rai. 2005. Yield attributes, yield and quality of soybean as influenced by integrated nutrient management. Indian J. Agron. 49: 271-274.

Tomar, S.S., R. Singh and P.S. Singh. 2004. Response of phosphorus, sulphur and Rhizobium inoculation on growth, yield and quality of soybean (Glycine max L.). Progress in Agril. Sci. 4: 72-73. 